\title{
EXAMINING THE FACTORS OF TAX NON- COMPLIANCE: A CASE STUDY OF SMALL AND MEDIUM ENTERPRISES IN METRO AREA
}

\author{
Marziana Mohamad*, Mohd Asri Mohd Ali \\ *Accounting Department, College of Business Management and Accounting \\ Universiti Tenaga Nasional
}

\begin{abstract}
Hidden income is a business income and individual income should be recorded and taxed but taxpayers are not reported in full or not reported at all. In this paper we examine the determinants of tax non-compliance among Small and Medium Enterprises (SMEs) in Metro area. 150 questionnaires were distributed to the three sectors namely, distribution, food and beverages, and service providers; only 86 agreed to participate (57.3\%). Kaiser-Meyer-Olkin, descriptive and Pearson correlation test were used to analyse the data. The results indicate that there was a number of significant relationship between tax incentive and company size towards tax non-compliance. Therefore, the importance of this phenomenon is the potential serious revenue losses to government and resulting in the possible under funding of public's service and also an unfair burden on honest citizens.
\end{abstract}

Keywords: Tax Compliance, Tax Knowledge, Fiscal Psychology Theory

\section{INTRODUCTION}

Tax compliance is referring to the willingness of taxpayers to act in accordance with both the spirit and the letter of the tax law and administration. Roth, Scholz and Witte (1989) defined tax compliance as filling all required tax return in proper of time and accurately report their tax liabilities with the tax law and regulation. In term of tax noncompliance, have two categories which are tax avoidance and tax evasion. Tax avoidance is a legal activity because tax laws are used to reduce the tax amount payable which denotes the taxpayers' ingenuity to arrange his affairs in a proper manner and any attempt to minimize tax is acceptable.

Tax evasion on the other hand is an illegal activity which involves a taxpayer's deliberate contravention of the tax law in order to eliminate tax liability by entails not filing income tax returns altogether or misrepresenting the tax liability amount. Tax evasion is the application of fraudulent practices in order to minimize or eliminate tax liability by making a false return of income by omitting or understating income or overstating expenses, making a false statement in a return affecting tax liability, giving false information on any matter affecting tax liability and other. Thus, tax avoidance and tax evasion will lead to the reduction or elimination of tax liability resulting into government revenues loss (www.taxation n-tz.com 2011). 
Based on the macroeconomic perspective, tax avoidance and tax evasion have similar negative effects on the national budget of a country. Kirchler, Maciejovsky and Scheider (2001) and Cross and Shaw (1982) reported that no longer found discrimination between tax evasion and tax avoidance. However, based on the psychological perspective, due to legal differences and moral considerations, Etzioni (1988) indicated that taxpayers perceive tax avoidance and tax evasion differently. The psychological dimension of tax avoidance and tax evasion has been analyzed from many perspectives, starting as early as the 1960 by "Cologne school of tax psychology" (Song and Yarbrough, 1978).

Otusanya (2011), also agreed that the tax avoidance and tax evasion reduced the government revenue. He found that the evidence from the cases examined has implicated MNCs (MultiNational Companies) in adopting a variety of tax avoidance and tax evasion schemes such as under-reporting their taxable profits and manipulating their accounting reports. Tax evasion has been a general and persistent problem throughout history with serious economic consequences such as hidden economy, not only in transition economics but also in countries with developed tax system.

Therefore, this study explores the perception of Small Medium Enterprises (SMEs) taxpayers in term of their level of tax noncompliance. This paper is organised as follows, review of literature, methodology and results. The last section includes some recommendations and direction for future research.

\section{REVIEW OF LITERATURE}

Tax knowledge is the level of awareness or sensitivity of the taxpayers to tax legislation. Tax knowledge also as an element in a voluntary compliance tax system, particularly in determining an accurate tax liability (Kasipillai, 2000; Palil, 2005). More recent studies investigate in Malaysia (Loo, McKerchar, Hansford, 2008; Loo, 2006; McKerchar, 2005) suggested that tax knowledge to be the most influential factor to determine taxpayers' compliance behavior under the selfassessment system (SAS). Kirchler and Niemirowski (2006) also stated that tax knowledge would lead the higher compliance rates.

Based on the economists per say, they have established a relationship between tax rates and the amount of tax evasion (Frey and Pommerehne, 1984; Trandel and Show, 1999). The higher the level of taxations shows the greater the incentive to participate in escape taxes. In a study done by Noor Suhaila and Sarifah (2008), majority of taxpayers from Small Medium Enterprises (SMEs) have low level of tax knowledge. They found that the lower of tax knowledge, it is resulting leads to tax noncompliance. Eriksen and Fallen (1996), also studies the level of tax knowledge taxpayers. The finding shows that the taxpayers have greater tax knowledge would comply the tax more efficiently compared to those with lower level of tax knowledge. It is means, higher level of education exposed more to tax matters and more knowledgeable about tax system in their countries.

In term of company size, there is a mixed evidence of finding between the company size and tax noncompliance level. According to Hanlon, Mills and Slemrod (2007), they found that have 
positive relationship between tax noncompliance and the company size. On the other hand, previous studies indicated that company size have a negative relationship with tax noncompliance. They found that the bigger the firms are, the more the firm complaint with the tax laws due to proper internal control, better accounting system and greater tax knowledge as compared to smallscale firms. Besides, Marinov (2008) stated that the socioeconomic reason for taxpayers to choose the decision to go underground or hidden income is influencing by the government policy in term of tax and regulation measures.

There are three theories of tax compliance, namely an economic deterrence model, fiscal psychology model and social psychology model. Firstly, economic deterrence model interpreted on the taxpayers compliance views such as perfectly moral, risk-neutral or risk averse individual who seek to maximize their utility and chose to evade tax. Secondly, for fiscal psychology model, consist economic deterrence model and social psychology model which is individuals are not simply independent utility maximizers but they are correlate with attitude and beliefs to respond of tax compliance (Hasseldine and Bebbington, 1991). Thirdly, social psychology model is examined the attitude and beliefs of taxpayers in order to understand and predict the human behavior. In this study, fiscal psychology model has chosen to examine the determinants of tax non-compliance. Hence, this study would like to investigate the factors of tax non-compliance among SMEs taxpayers in metro area, namely in Kuala Lumpur and Selangor. Therefore, the hypothesis are as follows:

$\mathrm{H}_{1} \quad$ : There is significant relationship between tax incentives towards tax noncompliance for SMEs.

$\mathrm{H}_{2}$ : There is significant relationship between company size towards tax noncompliance for SMEs.

\section{METHODOLOGY}

Data are collected from respondents consist of taxpayers who are doing small medium enterprises business (SMEs) in metro area namely in Kuala Lumpur and Selangor. One hundred fifty (150) SMEs taxpayers were selected randomly to distribute the questionnaires. Only 86 agreed to participate in this study which contributes to $57.3 \%$ response rate. The selected sectors are distribution trade, food and beverages, and services providers. The questionnaires is adapted from previous study which is Abdul Jabbar (2009), who studied on the tax compliance cost on noncompliance behavior of SMEs. The questionnaires are divided into four sections, namely Section A; respondents background, Section B; Knowledge on Tax Incentives, Section C; Perception of Company size and Section D; perception on tax non-compliance. 


\section{RESULTS AND DISSCUSION}

\section{Reliability Test}

Cronbach's alpha has been used to test the reliability of questioner's which has set by researcher. Reliability test has conducted on 3 dimensions which respectively are tax incentives, company size and tax noncompliance. The finding shows that all variable is above 0.7 which is acceptable in this study (Table 1).

\begin{tabular}{lcc}
\hline Reliability test & Cronbach's Alpa & No item \\
\hline Tax Incentives & 0.697 & 6 \\
Company size & 0.770 & 8 \\
Tax Non-compliance & 0.720 & 5 \\
\hline
\end{tabular}

Table 1: Reliability Analysis

\section{Factor Analysis}

Factor analysis has been applied to explore the underlying factors associated with 19 items by using Principal Component Analysis (PCA). The value of KMO varies from 0 to 1, and KMO overall should be 0.60 or higher to perform factor analysis. Result for the Bartlett's Test of Sphericity and the KMO reveal that both were highly significant and concluded that this variables was suitable for the factor analysis which is 0.713 (Table 2).

\begin{tabular}{lll}
\hline Kaiser-Meyer-Olkin Measure of Sampling Adequacy & 0.713 \\
\hline Bartlett's Test of Sphericity & Approx. Chi-Square & 534.731 \\
& df & 171 \\
& Sig. & 0.000 \\
\hline
\end{tabular}

Table 2: KMO and Bartlett's Test

\section{Descriptive Analysis}

Analysis of the profile of the respondents indicates that an equal percentage between female and male respondents which is $50 \%(n=43)$ respectively. About $43 \%(n=37)$ of the respondents are senior position, $25.6 \%(\mathrm{n}=22)$ are junior position, $22.1 \%(\mathrm{n}=19)$ are managers and $9.3 \%(\mathrm{n}=8)$ are partners.

Table 3 shows the information about the respondents' perception on tax non-compliance. The results indicate that the average of SMEs perception towards tax non-compliance is 2.9767 which is 'neutral'. It is means, some of SMEs taxpayers either agree or disagree with the following statement. 


\begin{tabular}{|l|l|c|c|}
\hline No. & Measures & Mean & Std. Deviation \\
\hline 1 & Tax non-compliance is not a serious offense. & 2.6744 & 1.12136 \\
\hline 2 & Tax non-compliance does not compromised one's integrity. & 2.5814 & 0.87401 \\
\hline 3 & $\begin{array}{l}\text { Tax non-compliance should be allowed if the reason to do so can } \\
\text { be justified. }\end{array}$ & 3.2558 & 1.03112 \\
\hline 4 & $\begin{array}{l}\text { Tax non-compliance is more towards tax evasion (a criminal } \\
\text { offense) than tax avoidance (not a criminal offense). }\end{array}$ & 3.0814 & 1.15009 \\
\hline 5 & $\begin{array}{l}\text { Tax non-compliance is more towards tax avoidance (not a criminal } \\
\text { offense) than tax evasion (a criminal offense). }\end{array}$ & 3.2907 & 1.03885 \\
\hline & \multicolumn{1}{|c|}{ Average } & 2.9767 & 1.04309 \\
\hline
\end{tabular}

Table 3: Perception on Tax Non-Compliance

\section{Hypotheses Testing}

Table 4 presents correlation results of the study. The $p$ value results shows that all variable have significant relationship with tax noncompliance. In term of tax incentive, there is a significant relationship with tax noncompliance which is $\mathrm{p}$ value 0.046 . Previous studies have evidence that general tax knowledge has a very close relationship with taxpayers' ability to understand the laws and regulations of taxation (Singh, 2003). Therefore, this hypothesis $\left(\mathrm{H}_{1}\right)$ is supported and consistent with previous studies.

Then, for company size also shows significant relationship towards tax noncompliance. The $\mathrm{p}$ value is less than 0.05 which is the p value is 0.035 . Hanlon, Mills and Slemrod (2007) indicate that there is a significant relationship between business size and tax non-compliance of corporate taxpayers. Therefore, this hypothesis $\left(\mathrm{H}_{2}\right)$ is supported and consisted with previous studies.

\begin{tabular}{llrr}
\hline & & CS & \multicolumn{2}{c}{ TI } \\
\hline Tax & Pearson Correlation & $\mathbf{. 2 2 7}^{*}$ & $\mathbf{. 2 1 6}^{*}$ \\
Noncompliance & Sig. (2-tailed) & $\mathbf{. 0 3 5}$ & $\mathbf{. 0 4 6}^{*}$ \\
(TNC) & $\mathrm{N}$ & 86 & 86
\end{tabular}

* Correlation is significant at the 0.05 level (2-tailed)

Table 3: Perception on Tax Non-Compliance

\section{CONCLUSION AND RECOMMENDATION}

The objective of this study is to examine the determinants of tax non-compliance among SMEs and their perception on the tax law and regulations. The results indicate that tax incentive and company size are significantly related to the tax noncompliance. This study shows that strong desire of taxpayers to comply the tax obligations determined by the tax incentive and company size towards tax non-compliance. This suggest that one of the target of this paper is to explain the factors that affect compliance in taxation through Fiscal Psychology Model can be realized. 
In order to improve the tax compliance, it is very important for SMEs taxpayers to enroll in at least one of the tax education. This is because general level of education is not sufficient enough. In a study by Loo and Ho (2005), investigate the group of salaried individuals in Melaka, Malaysia, they found that the taxpayers competency level is quite low even though most of them have tertiary education. Previous studies also have evidenced that tax knowledge play an important role in increasing tax compliance. However, this study cannot be generalized to all taxpayers, since it is only being conducted to the SMEs in metro area namely Kuala Lumpur and Selangor. Besides, tax evasion and tax avoidance are an important phenomenon that affects to countries such as potential serious revenue losses to government.

\section{REFERENCES:}

Abdul Jabbar, H. (2009). Income Tax Non-compliance of Small and Medium Enterprises in Malaysia: Determinants and Tax Compliance costs. Unpublished doctoral dissertation, Curtin University of Technology, Perth, Australia

Cross, R.B., and Shaw, G.K. (1982). Tax Evasion-avoidance choice: A Suggested Approach. National Tax Journal, 34,489-491

Eriksen, K. and fallan, L. (1996). Tax Knowledge and Attitudes towards Taxation: A Report on a Quasi-experiment, Journal of Economic Psychology, 17, 387-402

Etzioni, A. (1988). The Moral Dimension. Towards a new Economy, New York: Free Press

Hanlon, M., Mills, L., and Slemrod, J. (2007). An Empirical Examination of Corporate Tax Noncompliance. Cambridge University Press. 171-210

Hasseldine, D., and Bebbington, K. J. (1991). Blending Economic Deterrence and Fiscal Psychology Models in theDesign of Responses to Tax Evasion: The New Zealand

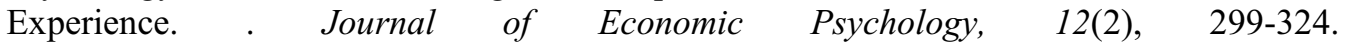
http://dx.doi.org/10.1016/0167-4870 (91)90018-O

Kasipillai, J. (2000). A Practical Guide to Malaysian Taxation-Current Year Assessment, Kuala Lumpur, McGraw-Hill, New York

Kirchler, E., Maciejovsky, B., and Scheider, F. (2001). Everyday representations of Tax Avoidance, Tax Evasion and Tax Flight: Do not legal differences matter? Journal of Economic Psychology, vol. 24, 535-553

Kirchler, E., Niemirowski, A. (2006). Wearing, Shared Subjective views, intent to cooperate and Tax Compliance: Similarities between Australian Taxpayers and Tax Officer, Journal of Economic Psychology, 27(4), 502-517

Loo, E.C. (2006). The influences of the introduction on Self Assessments on Compliance Behavior of individual taxpayers in Malaysia, $\mathrm{PhD}$ thesis, University of Sydney

Loo, E.C. and Ho, J.K. (2005). Competency of Malaysia Salaried Individuals in Relation to Tax Compliance under Self-Assessment. http://www.austlii.edu.au/au/journals/eJTR/2005

Loo, E.C., Mckerchar, M. and Hansford, A. (2008). Tax Compliance Behavior: Finding derived from a mixed method design, Proceeding of $8^{\text {th }}$ International Tax Administration Conference, Sydney

Marinov, A. (2008). Hidden Economy in the Rural Regions of Bulgaria. International Review on Public and Nonprofit Marketing. 5, 71-81 
Noor Suhaila, S., and Sarifah, I. (2008). Factors influencing the level of Tax Compliance: A Case Study of Small Business Entrepreneurs Hentian Nilai, Negeri Sembilan, Selangor International Islamic University College.

Otusanya, O.J. (2011). The role of multinational companies in tax evasion and tax avoidance: The case of Nigeria. Critical Perspectives on Accounting. V22. 316-332

Palil, M.R. (2005). Does Tax Knowledge matter in Self-Assessment System? Evidence from the Malaysian Tax Administration, Journal of American Academy of Business, 6 (2), 80-85

Roth, J.A., Scholz, J.T. and Wittee, A.D. (1989). Taxpayers Compliance: An Agenda for Research, University of Michigan Press, Philadelphia, PA

Sekaran, U. (2003). Research Methods for Business: A Skill Building Approach, New York: John Wiley \& Sons

Singh, V. (2003). Malaysian Tax Administration, $6^{\text {th }}$ Ed. Longman, Kuala Lumpur

Song, Y.D. and Yarbrough, T.E. (1978). Tax Ethics and Tax Attitudes: A Survey. Public Administration Review, 38. 442-452 